\title{
MENCIPTAKAN PUSTAKAWAN UNGGUL MELALUI KEGIATAN MENULIS KARYA ILMIAH DI UPT PERPUSTKAAN UNIVERSITAS JEMBER
}

\section{Khusnun Nadhifah}

Universitas Jember

email: Khusnun.library@gmail.com

\begin{abstract}
Abstrak
SDM unggul dapat diwujudkan melalui pustakawan yang berkompeten yaitu pustakawan dengan memiliki pendidikan dan/atau pelatihan kepustakawanan serta melakukan pengembangan profesi berupa penulisan karya tulis ilmiah. Data menunjukkan bahwa keterlibatan pustakawan di Universitas Jember (UNEJ) antara 6,67\% - 26,67\% yang berkontribusi pada penulisan karya ilmiah. Hal ini diperlukan motivasi dan solusi pustakawan UNEJ untuk meningkatkan jumlah karya tulis ilmiah. Permasalahan dalam penelitian ini adalah bagaimana upaya Perpustakaan UNEJ memberikan motivasi dan solusi pada pustakawan untuk menghasilkan dan meningkatkan jumlah karya tulis ilmiah. Tujuan penelitian yaitu menganalisis upaya Perpustakaan UNEJ dalam memberikan motivasi dan solusi pada pustakawan untuk menghasilkan dan meningkatkan jumlah karya tulis ilmiah. Metode penelitian menggunakan metode deskriptif (studi kasus). Penelitian dilakukan pada Januari - Juli 2020. Sumber data menggunakan data primer dan sekunder. Subyek penelitian 15 pustakawan dengan teknik pengumpulan data berupa observasi dan wawancara pada 7 responden berdasarkan teknik purposive sampling. Hasil penelitian menunjukkan, hambatan penulisan karya ilmiah adalah pustakawan tidak percaya diri, terbelenggu kegiatan rutinitas, minim penguasaan kepenulisan dan rasa malas untuk menulis karya ilmiah. Motivasi dan solusinya adalah memberikan statemen pada pustakawan bahwa menulis bukanlah sebuah bakat, tetapi menulis adalah sebuah proses dari membaca dan latihan menulis, menulis bukan beban berat tetapi mencatat apa yang dikerjakan, meningkatkan kepercayaan diri pada pustakawan, menyempatkan waktu untuk menulis di sela-sela kesibukan rutinitasnya. meningkatkan kompetensi pustakawan bidang kepenulisan, meningkatkan minat baca pustakawan.
\end{abstract}

\section{A. PENDAHULUAN}

Pemerintah terus berupaya agar Indonesia menjadi negara maju dan diterima sejajar dengan negara lain, Upaya tersebut diantaranya dengan meningkatkan potensi sumber daya manusia (SDM). Presiden Indonesia Joko Widodo pada periode kedua dalam salah satu visinya adalah membangun sumber daya manusia (SDM) dan meningkatkan kualitas pendidikan. Pembangunan pemerintah difokuskan pada pembangunan SDM sebagai kunci yang menentukan kemajuan bangsa karena negara yang maju selalu didukung SDM berkualitas (Indrawati, 2019). Pustakawan merupakan SDM yang berperan besar dalam peningkatan kualitas pendidikan. Untuk itu dibutuhkan pustakawan yang berkompeten dalam rangka mewujudkan proses pendidikan yang berkualitas.

Salah satu upaya menciptakan SDM yang unggul adalah mewujudkan pustakawan yang berkualitas/berkompeten. Menurut Perpustakaan Nasional RI (2012) pustakawan adalah seseorang yang memiliki kompetensi yang diperoleh melalui pendidikan dan/atau pelatihan kepustakawanan. Pustakawan yang berkompeten adalah pustakawan yang mampu melaksanakan pekerjaan yang dilandasi oleh pengetahuan, keterampilan dan sikap kerja dalam menyelesaikan suatu pekerjaan serta mempunyai tugas dan tanggung jawab 
untuk melaksanakan pengelolaan dan pelayanan perpustakaan. Terdapat 6 pemetaan standar kompetensi, yaitu 1) Pengembangan koleksi perpustakaan, 2) Pengorganisasian bahan perpustakaan, 3) Layanan perpustakaan, 4) Pelestarian bahan perpustakaan, 5) Pengembangan profesi dan sistem kepustakawanan, 6) Manajemen perpustakaan, 7) Penerapan teknologi informasi dan komunikasi.

Poin ke-5 yaitu pengembangan profesi dan sistem kepustakawanan difokuskan pada kegiatan menulis yang termasuk di dalamnya adalah pembuatan karya tulis ilmiah. Butir-butir kegiatan pada pengembangan profesi tersebut memberikan penegasan bahwa semua jenjang jabatan pustakawan diharapkan dapat memberikan sumbangsih berupa pemikiran yang dituangkan dalam bentuk tulisan. Bahkan pada jenjang jabatan pustakawan keahlian menjadi kewajiban membuat karya tulis sebagai persyaratan kenaikan pada jenjang jabatan pustakawan yang lebih tinggi. Sehingga kegiatan menulis karya ilmiah bagi pustakawan bukan sekedar kebutuhan tetapi menjadi kewajiban guna menjalankan tugas pokok dan fungsinya.

Kenyataan menunjukkan bahwa pustakawan yang menulis karya ilmiah pada beberapa kegiatan kepenulisan seperti call for paper, submit jurnal, serta kegiatan kepenulisan lain adalah pustakawan tertentu saja. Seperti contoh, penulis yang mengirim artikel di prosiding seringkali adalah penulis yang sama pada jurnal atau media penulisan lain. Data menunjukkan bahwa keterlibatan pustakawan di Universitas Jember (UNEJ) masih sedikit yang berkontribusi dalam dunia penulisan karya ilmiah. Berikut adalah tabel Kontribusi pustakawan UNEJ yang telah memberikan sumbangsih dalam penulisan karya tulis ilmiah.
Tabel 1. Kontribusi Pustakawan UNEJ Menulis Karya IImiah

\begin{tabular}{|c|c|c|c|}
\hline \multirow{2}{*}{ Tahun } & \multicolumn{2}{|c|}{ Jumlah } & \multirow{2}{*}{$\begin{array}{c}\text { Persentase } \\
\text { (\%) }\end{array}$} \\
\cline { 2 - 3 } & $\begin{array}{c}\text { Pustakawan } \\
\text { Menulis }\end{array}$ & $\begin{array}{c}\text { Pustakawan } \\
\text { UNEJ }\end{array}$ & \\
\hline 2016 & 4 & 15 & $26,67 \%$ \\
\hline 2017 & 4 & 15 & $26,67 \%$ \\
\hline 2018 & 1 & 15 & $6,67 \%$ \\
\hline 2019 & 1 & 15 & $6,67 \%$ \\
\hline
\end{tabular}

Tabel 1 menunjukkan bahwa persentase pustakawan UNEJ yang berKontribusi dalam penulisan karya ilmiah sangat kecil (6,67\% sampai dengan 26,67\%). Kondisi ini diperlukan motivasi dan solusi pustakawan UNEJ untuk menghasilkan karya tulis ilmiah.

Permasalahan dalam penelitian ini adalah bagaimana upaya Perpustakaan UNEJ memberikan motivasi dan solusi pada pustakawan untuk menghasilkan dan meningkatkan jumlah karya tulis ilmiah. Tujuan penelitian yaitu menganalisis upaya Perpustakaan UNEJ dalam memberikan motivasi dan solusi pada pustakawan untuk meningkatkan jumlah karya tulis ilmiah.

\section{B. METODE PENELITIAN}

Metode penelitian menggunakan metode deskriptif (studi kasus) yaitu memberi gambaran variabel masa lalu, sekarang atau yang sedang terjadi (Siyoto, 2015). Memberi gambaran tentang upaya Perpustakaan UNEJ dalam memberikan motivasi dan solusi pada pustakawan UNEJ untuk menghasilkan karya tulis ilmiah. Penelitian dilakukan pada Januari - Juli 2020. Penelitian juga ditunjang literatur tentang motivasi dan solusi tentang kepenulisan. Sumber data yaitu data primer dan sekunder. Subyek penelitian sejumlah 15 pustakawan dan teknik pengumpulan data berupa observasi dan wawancara pada 7 responden berdasarkan teknik purposive sampling. 


\section{HASIL DAN PEMBAHASAN}

Berdasarkan observasi dan wawancara dengan pustakawan UNEJ, hasil penelitian menunjukkan bahwa yang menjadi hambatan kegiatan menulis karya ilmiah adalah:

1). Pustakawan tidak percaya diri terhadap karya ilmiah yang telah ditulis karena merasa takut akan kesalahan, tulisan dianggap kurang berkualitas dan merasa malu jika dibaca orang lain.

2). Pustakawan terbelenggu oleh kegiatan rutinitas sehingga terkendala oleh waktu untuk membaca dan berlatih menulis karya ilmiah.

3). Minimnya pustakawan menguasai keterampilan menulis sehingga mempunyai perasaan bahwa menulis karya ilmiah dianggap sebuah beban berat. Hal ini menyebabkan pustakawan merasa kesulitan menuangkan ide/gagasan dalam sebuah tulisan. Jika ide/ gagasan telah muncul, kesulitan berikutnya adalah sulit untuk memulai menulis karya ilmiah serta sulit dalam mengembangkan kata menjadi sebuah kalimat yang baik.

4). Pustakawan merasa malas mengembangkan potensi dirinya melalui kegiatan menulis karya ilmiah. Beberapa penyebab kemalasan disebabkan oleh tidak adanya ide/gagasan yang akan dituangkan dalam tulisan karya ilmiah.

\section{Motivasi dan solusi Pustakawan Menulis}

\section{Karya IImiah}

Dari berbagai hambatan dapat diberikan motivasi sebagai solusi pustakawan UNEJ dengan harapan dapat meningkatkan minat menulis karya ilmiah, yaitu

1. Memberikan motivasi kepada pustakawan dengan statemen bahwa menulis bukanlah sebuah bakat, tetapi menulis adalah sebuah proses dari membaca dan latihan menulis. Proses tersebut dikenal dengan istilah $3 \mathrm{~B}+3 \mathrm{~L}$ yaitu baca, baca, dan baca dan $3 \mathrm{~L}$ yaitu latihan, latihan, dan latihan (Prasetyo, 2020). Upaya Perpustakaan UNEJ dalam peningkatan minat baca berupa kegiatan konferensi kepustakawanan (Nadhifah, 2019), yaitu mengkaji ulang dan mempresentasikan kembali pengetahuan yang telah diperoleh pada kegiatan pustakawan di luar daerah, dilakukan kegiatan bazar buku dengan berkolaborasi pada penerbit seperti Jelajah Kata, Agromedia dan Erlangga. Peningkatan minat baca dari pustakawan sendiri dapat diwujudkan dengan bergabung pada komunitas kepenulisan seperti Kelompok Pustakawan Menulis (KMP), media sosial seperti whatsApp grup kepenulisan yang sedang trend saat ini. Komunitas whatsApp grup kepenulisan ada yang tidak berbayar memberikan manfaat yaitu tidak memakan waktu lama karena waktu yang tersedia sangat terbatas yaitu 1 hari saja, tidak membosankan karena bisa dilakukan dengan kondisi apa pun dan hasilnya sangat efektif untuk meningkatkan pengetahuan tentang kepenulisan.

2. Memberikan Mindset/pola pikir kepada pustakawan bahwa menulis karya ilmiah bukan suatu beban berat. Menulis pada dasarnya mencatat apa yang dikerjakan pustakawan setiap hari/pekerjaan rutin. Melakukan pencatatan berdasar fakta sehari-hari dan menganalisis dari setiap permasalahan yang muncul. Akan tetapi pustakawan masih kurang mampu menganalisis permasalahan tugas dan pekerjaannya sehingga tidak memiliki ide dan inspirasi membuat karya tulis (Nasihuddin, 2017). Untuk itu diperlukan pembelajaran secara terus menerus agar pustakawan mempunyai kepekaan yang tajam dalam menganalisis permasalahan dalam pekerjaan rutinitasnya menghasilkan sebuah karya tulis ilmiah. UPT 
Perpustakaan UNEJ dalam membangun pola pikir tersebut dengan meningkatkan kompetensi pustakawan di bidang ketrampilan/ keahlian menulis karya ilmiah. Perpustakaan UNEJ aktif bergabung pada kegiatan kepenulisan bidang kepustakawanan seperti call for paper, call for write dan seminar/ workshop tentang kepenulisan. Call for paper dapat mengasah keterampilan menulis dan meningkatkan branding pustakawan serta membentuk pustakawan yang berkompeten dalam bidang menulis dan public speaking (Hardiningtyas, 2016)

3. Meningkatkan kepercayaan diri (Self Confidence) pada pustakawan. Kepercayaan diri merupakan kemampuan seseorang untuk menampilkan perilaku tertentu untuk mencapai sebuah target (Adywibowo, 2010). Kegiatan dapat tercermin melalui peningkatan soft skill dan hardskill. Meningkatkan soft skill seperti menjadi presenter lokal untuk sosialisasi perpustakaan pada pengenalan mahasiswa baru, pembinaan kepustakawanan pada petugas ruang baca di fakultas. Peningkatan kualitas hard skill diantaranya memberikan kesempatan kepada pustakawan untuk melanjutkan pendidikan pada jenjang yang lebih tinggi serta aktif terlibat dalam uji kompetensi maupun uji sertifikasi (Nadhifah, 2019). Sedangkan kepercayaan diri dari pustakawan itu sendiri juga harus dibangun melalui:

a). Motivasi/dukungan dari diri sendiri yang kuat untuk selalu belajar menulis karya ilmiah. Dukungan dari diri sendiri memberikan peran besar dalam proses menulis, karena tidak bisa dipaksakan oleh orang lain untuk tetap selalu menulis karya ilmiah.

b). Memberanikan diri, selalu melatih dan mengasah kemampuan untuk menulis karya ilmiah. Karena menulis karya ilmiah tidak datang secara otomatis, melainkan harus dilakukan pembelajaran secara rutin serta praktik yang teratur.

c). Selalu berpikir positif terhadap karya ilmiah yang telah ditulis.

d). Menerima kegagalan sebagai bentuk pembelajaran yang terbaik.

e). Tetap semangat dan tidak mudah menyerah dan selalu produktif untuk menulis karya ilmiah.

4. Pustakawan sebaiknya menyempatkan waktu untuk melakukan proses menulis di sela-sela kesibukan rutinitasnya. Manajemen waktu menjadi kontrol utama dalam poin ini. Perlunya penjadwalan/pengaturan waktu antara mengerjakan rutinitas dan melakukan kegiatan menulis karya ilmiah untuk setiap hari, setiap minggu atau bahkan setiap bulan. Melalui manajemen waktu akan tampak target dan hasil yang diharapkan. Misal, dengan menetapkan target dalam 1 tahun menghasilkan 1 karya tulis ilmiah.

Upaya UPT Perpustakaan UNEJ dalam meningkatkan pustakawan menghasilkan karya tulis ilmiah dapat dilihat pada Tabel 2.

Tabel 2. Kontribusi Pustakawan UNEJ Menulis Karya IImiah

\begin{tabular}{|c|c|c|c|}
\hline \multirow{2}{*}{ Tahun } & \multicolumn{2}{|c|}{ Jumlah } & \multirow{2}{*}{$\begin{array}{c}\text { Persentase } \\
\text { (\%) }\end{array}$} \\
\cline { 2 - 3 } & $\begin{array}{c}\text { Pustakawan } \\
\text { Menulis }\end{array}$ & $\begin{array}{c}\text { Pustakawan } \\
\text { UNEJ }\end{array}$ & $26,67 \%$ \\
\hline 2016 & 4 & 15 & $26,67 \%$ \\
\hline 2017 & 4 & 15 & $6,67 \%$ \\
\hline 2018 & 1 & 15 & $6,67 \%$ \\
\hline 2019 & 1 & 15 & $26,67 \%$ \\
\hline 2020 & 4 & 15 & \\
\hline
\end{tabular}

Tabel 2 menjelaskan terdapat kenaikan jumlah pustakawan dalam menulis karya tulis ilmiah sebesar 4 orang (20\%). Hal ini menunjukkan bahwa UPT Perpustakaan UNEJ berhasil memotivasi dan memberikan solusi kepada pustakawan dalam meningkatkan jumlah karya tulis ilmiah. 


\section{Pentingnya Menulis Karya Ilmiah mewujudkan Pustakawan Unggul}

Keterampilan menulis pada dasarnya sudah diajarkan sejak kita mulai masuk Sekolah Dasar (SD) bahkan di bangku Taman Kanak-kanak kegiatan menulis sudah mulai diperkenalkan. Pentingnya menulis diperkenalkan mulai SD adalah agar anak-anak sejak dini terlibat dalam kegiatan baca tulis. Keterlibatan tersebut merupakan bentuk pembelajaran dasar menulis yang dapat menentukan proses menulis pada tahap selanjutnya. Menulis merupakan kegiatan mengungkapkan gagasan/ide secara tertulis dengan hasil kegiatan yang disebut tulisan untuk dibaca orang lain agar gagasan yang disampaikan penulis dapat diterima oleh pembaca (Wiyanto, 2004).

Sedangkan menulis karya ilmiah adalah sebuah kegiatan intelektual yang merupakan bagian dari sebuah keterampilan dan keahlian/skill yang harus dimiliki pustakawan untukmenghasilkan sebuah karya yang bermanfaat pada masyarakat. Melalui menulis karya ilmiah pustakawan dapat meningkatkan kreativitas mencari ide, berpikir, merangkai kata menjadi sebuah kalimat, mencari sumber literatur serta berimajinasi untuk mendukung karya tulis ilmiahnya. Alasan pentingnya pustakawan menulis karya ilmiah selain sebagai pemenuhan kewajiban dalam upaya kenaikan jabatan fungsional pustakawan, menulis karya ilmiah juga mendapat penilaian angka kredit tinggi pada unsur pengembangan profesi. Nilainya akan lebih tinggi lagi jika karya tulis ilmiah tersebut dipublikasikan pada media kepenulisan yang diakui secara nasional maupun internasional.

Sebagai pustakawan yang bertugas secara rutin berada di lingkungan akademik dan berkecimpung dengan berbagai macam sumber informasi, memberikan peluang sangat tinggi dalam menuangkan gagasan/ide secara tertulis. Pustakawan dengan mudah mendapatkan sumber referensi dalam mendukung karya tulis ilmiahnya, sehingga menjadi hal yang wajar jika pustakawan seharusnya memberikan banyak sumbangsih dalam dunia karya tulis ilmiah. Jangan sampai terjadi seperti apa yang dikatakan pepatah yaitu tikus mati di lumbung padi yang dapat diartikan pustakawan berada dalam lumbung informasi tetapi "mati"/tidak dapat melahirkan sebuah karya tulis ilmiah karena belum dapat memanfaatkan sumber informasi yang dimiliki secara maksimal.

Jika pustakawan sudah terbiasa menulis karya ilmiah, secara tidak langsung dirinya menjadi pustakawan yang unggul, yaitu pustakawan yang dapat memberikan nilai lebih di antara pustakawan lainnya. Unggul menurut Kamus Besar Bahasa Indonesia artinya lebih tinggi. Pustakawan unggul dapat diartikan sebagai pustakawan yang mempunyai nilai keahlian lebih diantaranya keahlian menulis karya ilmiah serta unggul dalam berpikir kritis karena pustakawan terlibat langsung dalam proses berpikir tingkat tinggi yaitu analisis, sintesis dan evaluasi yang dapat melahirkan berpikir kritis. Berpikir kritis merupakan gabungan antara sikap, pengetahuan dan keterampilan yang meliputi sikap penyelidikan yaitu kemampuan mengetahui adanya masalah dan penerimaan bukti umum untuk melakukan abstraksi, dan generalisasi secara logis.

Jika pustakawan ingin dikenal dan dikenang pada masa yang akan datang maka ciptakan karya tulis. Seorang sastrawan ternama dari Blora, Pramoedya Ananta Toer mengatakan "Menulislah, karena tanpa menulis engkau akan hilang dari pusaran sejarah". Selain itu dia juga mengatakan "Orang boleh pandai setinggi langit, tapi selama ia tidak menulis, ia akan hilang di dalam masyarakat dan dari sejarah". Menulis adalah bekerja untuk keabadian. Tulisan juga menunjukkan tingkat peradaban sebuah bangsa. Seperti halnya zaman prasejarah dan zaman sejarah yang membedakan 
adalah adanya tulisan. Zaman prasejarah belum mengenal tulisan sehingga tidak bisa mengabadikan peristiwa penting pada saat itu.

\section{PENUTUP}

\section{Simpulan}

Pustakawan merupakan SDM profesional yang mempunyai kewajiban menuangkan gagasannya dalam bentuk tulisan. Salah satu diantaranya adalah dalam bentuk karya tulis ilmiah. Agar pustakawan termotivasi melakukan kegiatan menulis karya ilmiah, pustakawan harus meningkatkan kompetensi dirinya melalui membaca, bergabung dalam komunitas kepenulisan dan meningkatkan percaya diri untuk terus berlatih dan meningkatkan kegiatan menulis karya ilmiah. Kegiatan kepenulisan pustakawan saat ini sudah menjamur sehingga dapat memberi motivasi dan harapan besar bagi kemajuan pustakawan Indonesia dalam menulis karya ilmiah.

\section{DAFTAR PUSTAKA}

Adywibowo. (2010). Memperkuat kepercayaan diri anak melalui percakapan referensia. Jurnal Pendidikan Penabur, 15(9), 37-49.

Hardiningtyas, T. (2016). Komunitas Pustakawan Menulis:Upaya Menyebarluaskan dan Melestarikan Pengetahuan. Jurnal Pustaka IImiah, 15(1), 163-172.

Indrawati, S. M. (2019). Menuju Indonesia Maju Melalui SDM Unggul. Retrieved from Pusat Kajian Pengembangan Diri Berdikari.

Nadhifah, K.(2019).Kompetensi Pustakawan:Program Strategi Peningkatan Kualitas Pustakawan Di Perpustakaan Universitas Jember. Universitas Airlangga.

Nasihuddin, W. (2017). Peningkatan Status dan Eksistensi Profesi Pustakawan Indonesia melalui Publikasi Bidang Kepustakawanan. Media Pustakawan, 24(1), 37-48.
Prasetyo, T. (2020). Menentukan Target Menulis. Retrieved from https://indonesiatera.com/ menentukan-target-menulis/

Wiyanto, A. (2004). Terampil Menulis Paragraf. Jakarta: Grasindo. 